\title{
Terug van weggeweest: een verkenning van verticale prijsbinding in het Europese en Nederlandse mededingingsrecht
}

\author{
Mr. J.B. van der Blij en mr. dr. T.D.O. van der Vijver*
}

Met de publicatie van de 'Leidraad. Afspraken tussen leveranciers en afnemers' onderstreept de ACM de nieuw ingeslagen weg met betrekking tot verticale prijsbinding: er zal meer aandacht bestaan voor en strenger worden opgetreden tegen verticale prijsbinding. Deze actievere handhaving staat duidelijk in contrast met het (prioriterings)beleid dat de ACM slechts vier jaar eerder uiteenzette in het Visiedocument over verticale afspraken. De nieuwe koers is mede ingegeven door de vlucht die internetverkoop heeft genomen en zorgt ervoor dat de ACM weer in pas loopt met de Commissie (en de rest van de EU-lidstaten).

ACM, 'Leidraad. Afspraken tussen leveranciers en afnemers', 26 februari 2019, https://mmm.acm.nl/sites/ default/files/documents/leidraad-afspraken-tussenleveranciers-en-afnemers.pdf

\section{Inleiding}

Verticale prijsbinding, oftewel Resale Price Maintenance (RPM), leidde jarenlang een sluimerend bestaan in het Europese en het Nederlandse mededingingsrecht. RPM betekent kortgezegd dat een leverancier een distributeur verplicht een bepaalde wederverkoopprijs in acht te nemen. RPM is verboden, maar het leidde zelden tot boetes van de Europese Commissie (hierna: Commissie) of de Autoriteit Consument en Markt (ACM). De afgelopen jaren is bij deze autoriteiten de interesse voor RPM weer toegenomen. Dat komt vooral door de vlucht die internetverkoop heeft genomen. Met behulp van algoritmes is het voor leveranciers makkelijker om prijs-

Mr. J.B. (Bernadette) van der Blij is advocaat bij Allen \& Overy LLP in Amsterdam. Mr. dr. T.D.O. (Tjarda) van der Vijver is advocaat bij Allen \& Overy LLP in Amsterdam. Dit artikel bevat persoonlijke opvattingen die niet noodzakelijkerwijs de opvattingen zijn van Allen \& Overy LLP of haar cliënten. bewegingen in de gaten te houden, inclusief eventuele afwijkingen van het prijsniveau dat de leverancier graag zou zien op retailniveau. Deze transparantie kan ook leiden tot extra druk vanuit retailers op leveranciers, omdat (duurdere) retailers er belang bij hebben dat in een transparante markt geen grote prijsverschillen bestaan.

De hernieuwde interesse is al enige tijd duidelijk op Europees niveau. In juli 2018 legde de Commissie al vier boetes op voor RPM in de zaken Philips, Pioneer, Asus en Denon $\mathcal{E}$ Marantz. ${ }^{1}$ Dat waren de eerste Europese boetes voor dit vergrijp sinds 2003. ${ }^{2}$ Maar ook op het niveau van de EU-lidstaten zijn er ontwikkelingen. Verschillende mededingingsautoriteiten waaronder het Duitse Bundeskartellamt en de Britse Competition E Markets Authority zijn al langer ${ }^{3}$ actief op het gebied van RPM, en blijven onverminderd handhaven. ${ }^{4}$ Daarnaast

1. Besluit Commissie 24 juli 2018, zaak AT.40181 (Philips); Besluit Commissie 24 juli 2018, zaak AT.40182 (Pioneer); Besluit Commissie 24 juli 2018, zaak AT.40465 (Asus); Besluit Commissie 24 juli 2018, zaak AT. 40469 (Denon \& Marantz).

2. Persbericht Europese Commissie: 'Commission fines Yamaha for restrictions of trade and resale price maintenance in Europe', 16 juli 2003, te raadplegen via: http://europa.eu/rapid/press-release_IP-03-1028_en. htm?locale=en.

3. De Office of Fair Trading (OFT), de voorganger van de Britste Competition and Market Authority (CMA), publiceerde in 2004 al een guidancedocument ten aanzien van verticale overeenkomsten, waarin zij ook aandacht besteedt aan RPM. OFT, 'Vertical Agreements: Understanding competion law', december 2004, par. 7.7. Het Bundeskartellamt (BKA) legde in 2009 en 2010 al boetes op voor RPM aan Ciba Vision en Phonak. Zie: BKA Persbericht, 'Bundeskartellamt verhängt Bußgeld gegen Ciba Vision', 25 september 2009 en BKA Persbericht, 'Bundeskartellamt verhängt Bußgeld gegen Hörgerätegersteller Phonak $\mathrm{GmbH}^{\prime}, 15$ oktober 2010. In 2009 verklaarde de BKA al in een bijdrage voor een rondetafeldiscussie van de OECD dat de Europese benadering om RPM te zien als een hardcore-beperking juist is, en dat het een stap in de verkeerde richting zou zijn om RPM niet in het algemeen als mededingingsbeperkend te zien. Zie: OECD, 'Roundtable on Resale Price Maintanence', DAF/COMP(2008)/37, 10 september 2009.

4. De CMA bracht op 11 april 2019 nog het nieuws naar buiten dat zij een Statement of Objections heeft uitgebracht tegen Casio voor RPM. Persbericht CMA, 'CMA alleges piano supplier illegally prevented price discounts'. Op 21 juni 2016 bracht de CMA een advies naar buiten, 
zijn onder meer in Denemarken, België, Frankrijk en Griekenland recent boetes opgelegd voor RPM.

De ACM behoort tot de groep autoriteiten die RPM nu weer sterker in het vizier heeft. Waar de ACM eerder geen prioriteit gaf aan dergelijke overtredingen, makkte zij in december 2018 bekend vermeende afspraken over minimumprijzen tussen fabrikanten en winkeliers van consumentengoederen te onderzoeken. ${ }^{5}$ Ongeveer twee maanden later publiceerde de ACM haar nieuwe 'Leidraad. Afspraken tussen leveranciers en afnemers' (hierna: Leidraad), ${ }^{6}$ ter vervanging van het nog geen vier jaar oude visiedocument dat zij eerder over dit onderwerp naar buiten bracht. ${ }^{7}$

RPM is dus een hot topic. Dit artikel behandelt de recente ontwikkelingen op het gebied van RPM, en legt daarbij de nadruk op (de implicaties voor) het Nederlandse handhavingsbeleid. Dit artikel gaat vooral in op beleidsdocumenten en - waar beschikbaar - de beschikkingspraktijk van autoriteiten. Er bestaat vrijwel geen (recente) jurisprudentie van het Hof van Justitie die duidelijkheid schept over RPM. Voor enige richting vanuit het Hof van Justitie zullen we geduld moeten hebben tot het moment waarop die beschikkingspraktijk zal leiden tot mogelijke prejudiciële vragen aan, of beroepsprocedures in, Luxemburg.

\section{RPM en handhaving in het verleden}

\section{De basics van RPM}

Alvorens in te gaan op hoe het beleid van de ACM de afgelopen jaren is geëvolueerd en hoe zich deze ontwikkeling verhoudt tot de ontwikkeling bij andere mededingingsautoriteit, beginnen we bij het begin. Wat is RPM; wat is de onderliggende theory or harm; en wat zijn eventuele rechtvaardigingen voor RPM in de zin van efficiencies?

Afspraken tussen marktpartijen die de mededinging beperken, zijn verboden tenzij de concurrentiebeperkende effecten voldoende gecompenseerd kunnen worden door efficiencies. De Groepsvrijstelling inzake verticale overeenkomsten (hierna: de Groepsvrijstel-

gevolgd door een stevige open brief in juni 2017 aan leveranciers en retailers over de ernst van RPM, inclusief een casuspositie. Zie: CMA, 'Collection - Information for businesses: resale price maintenance (RPM)', op: www.gov.uk/government/publications/resale-price-mainte nance-advice-for-retailers/resale-price-maintenance-advice-for-retailers. Het BKA legde begin 2019 nog een boete op voor RPM. Persbericht BKA: 'Fine imposed on bicycle wholesaler ZEG for vertical price-fixing', 29 januari 2019.

5. Nieuwsbericht $A C M$ : 'ACM onderzoekt prijsafspraken tussen fabrikanten en winkeliers consumentengoederen', 27 december 2018.

6. ACM, 'Leidraad. Afspraken tussen leveranciers en afnemers', 26 februari 2019, www.acm.nl/sites/default/files/documents/leidraadafspraken-tussen-leveranciers-en-afnemers.pdf.

7. $\mathrm{ACM}$, 'Het toezicht van ACM op verticale overeenkomsten - Inzicht in strategie \& prioritering', 20 april 2015 www.acm.nl/sites/default/files/ old_publication/publicaties/14164_toezicht-acm-verticaleovereenkomsten.pdf. ling $)^{8}$ biedt voor verticale afspraken een generieke uitzondering op voornoemd verbod, onder bepaalde voorwaarden. Zo mag bijvoorbeeld geen sprake zijn van een hardcore-beperking. De Groepsvrijstelling omschrijft RPM als de beperking van de mogelijkheid tot het vaststellen van een wederverkoopprijs en merkt daarbij RPM aan als een hardcore-beperking. RPM valt dus buiten de Groepsvrijstelling en wordt (weerlegbaar) vermoed de concurrentie te beperken.

RPM kan direct plaatsvinden door een vaste (minimum)prijs, maar ook indirect. ${ }^{9}$ Voorbeelden van indirecte prijsbinding zijn het vastzetten van de marge van de distributeur, beperkingen ten aanzien van kortingen die de distributeur mag geven en het opschorten van levering of het hanteren van andere sancties door de leverancier in verband met de niet-inachtneming van een bepaald prijsniveau. Ook die indirecte vormen van RPM zijn dus niet vrijgesteld onder de Groepsvrijstelling.

In de Richtsnoeren met betrekking tot verticale beperkingen (hierna: de Richtsnoeren) noemt de Commissie diverse maatregelen die een vorm van RPM in de praktijk doeltreffender kunnen maken. ${ }^{10}$ Deze maatregelen kunnen op zichzelf dus niet als RPM worden gekwalificeerd, maar kunnen het effect ervan versterken. Voorbeelden hiervan zijn het gebruiken van prijscontrolesystemen en het (fysiek) aanbrengen van een adviesprijs op het product zelf. ${ }^{11}$ Het hanteren van pricing software die prijzen constant monitort, is dus geen inbreuk op zich, maar kan het effect van RPM zodanig versterken dat de Commissie extra reden heeft om handhavend op te treden. Dit was ook het geval in drie van vier zaken waarin de Commissie vorig jaar een boete oplegde. ${ }^{12}$

De Richtsnoeren noemen verschillende manieren waarop RPM schadelijk kan zijn voor de mededinging. ${ }^{13}$ In de kern verzwakt RPM (op zijn minst) de intrabrandconcurrentie, oftewel de concurrentie tussen distributeurs die hetzelfde merk verkopen. Immers, RPM ontneemt de mogelijkheid voor distributeurs om een bepaald product goedkoper te verkopen dan elders. Daarbij kan RPM afstemming tussen distributeurs in de hand werken of faciliteren. Zo kan RPM de transparantie over prijzen vergroten of zelfs (intrabrand-)concurrentie tussen distributeurs helemaal wegnemen. Zeker als RPM plaatsvindt op initiatief van de distributeurs, kan de prijsbinding ook ten grondslag liggen aan een verkapt kartel. Daarbij geldt voor zowel de verticale als

8. Verordening (EU) nr. 330/2010 van de Commissie van 20 april 2010 betreffende de toepassing van artikel 101, lid 3, van het Verdrag betreffende de werking van de Europese Unie op groepen verticale overeenkomsten en onderling afgestemde feitelijke gedragingen, PbEU 2010 , L 102/1.

9. Europese Commissie, Richtsnoeren inzake verticale beperkingen, $\mathrm{PbEU}$ 2010, C 130/1, par. 48 en 223-229.

10. Richtsnoeren, par. 48.

11. Richtsnoeren, par. 48

12. Besluit Commissie 24 juli 2018, zaak AT.40181 (Philips); Besluit Commissie 24 juli 2018, zaak AT.40182 (Pioneer); Besluit Commissie 24 juli 2018, zaak AT.40465 (Asus); Besluit Commissie 24 juli 2018, zaak AT. 40469 (Denon \& Marantz).

13. Richtsnoeren, par. 224. 
de horizontale dimensie dat hoe breder de toepassing van RPM is binnen de markt, hoe groter de kans is dat het geheel van afspraken de concurrentie beperkt.

RPM kan ook leiden tot efficiencies. De Richtsnoeren noemen diverse situaties waarin dat mogelijk het geval is. RPM kan nodig zijn om de lancering van een nieuw product te laten slagen, wat een positief effect kan hebben op concurrentie tussen merken (interbrand). Hetzelfde geldt voor het coördineren van kortingsacties binnen een franchise of soortgelijk distributiesysteem. Tot slot - en misschien wel de bekendste efficiëntie kan RPM meeliftproblemen voorkomen. Met de 'extra' marge die een hogere prijs oplevert, kan de wederverkoper presale services aanbieden, zoals advisering voor complexe producten. Zonder prijsbinding kunnen consumenten wel gebruikmaken van deze diensten, maar vervolgens hun product kopen bij een goedkopere aanbieder. Dit soort problemen kan zich vaker voordoen gelet op de opkomst van online winkels, die mogelijk meeliften op het advies en de diensten die worden geleverd in fysieke winkels. ${ }^{14}$

\section{(Uitblijven van) handhaving door de ACM}

Hoewel RPM in de Groepsvrijstelling wordt aangemerkt als een hardcore-beperking, heeft de ACM in het verleden weinig actie ondernomen op dit gebied. ${ }^{15}$ Toch zijn de recente invallen niet de eerste keer dat de ACM in beweging komt. Naar aanleiding van een klacht legde de (toen nog) NMa in 1999 een last onder dwangsom op om een contractueel beding verwijderd te krijgen dat betrekking had op een verplichte verkoopprijs. ${ }^{16}$ Begin 2000 legde de NMa een boete op aan een groep van modeondernemingen die gebruikmaakten van RPM. De groep legde haar distributeurs prijsvoorschriften op door middel van 'minimumadviesprijzen', die dwingender bleken dan de term deed geloven. ${ }^{17}$ Dit besluit hield uiteindelijk geen stand voor de rechter, omdat het College van Beroep van het bedrijfsleven $(\mathrm{CBb})$ van oordeel was dat de NMa niet voldoende had aangetoond dat de beperking van de mededinging merkbaar is. ${ }^{18} \mathrm{Na}$

14. Zie bijvoorbeeld HR 16 september 2011, ECLI:NL:HR:2011:BQ2213 (Batavus/Vriens).

15. Zie voor een korte opsomming van RPM-handhaving in Nederland: Y. de Vries, N. Rutges en S. Vollering, 'Verticale prijsbinding geen prioriteit? Elders wel', Tijdschrift Mededingingsrecht in de Praktijk 2014, nr. 1, 2014/44

16. Besluit NMa 25 maart 1999, zaak 570 (Free Record Shop/Erasmus Muziekproducties). De NMa trekt hier onder meer de conclusie dat '[h]et opleggen van verticale prijsbinding [...] een ernstige inbreuk [is] op de Mw.'

17. Besluit ACM 12 januari 2000, zaak 757(Chilly en Basilicum versus GStar/Secon Groep), besluit te vinden op www.acm.nl.

18. CBb 7 december 2005, ECLI:NL:CBB:2005:AU8309, r.o. 6.5. Overigens is die discussie over merkbaarheid inmiddels naar de achtergrond geschoven, aangezien het Expedia-arrest heeft bevestigd dat bij een doelbeperking (waar RPM als hardcore-beperking onder kan worden geschaard) geen aparte analyse hoeft te worden gemaakt naar de merkbaarheid daarvan. Zie HvJ 13 december 2012, zaak C-226/11, deze uitspraak zette de NMa het RPM-dossier in de ijskast. In een toespraak bij de Vereniging voor Mededingingsrecht in 2006 lichtte de toenmalig NMa-voorzitter Kalbfleisch toe dat zaken van minimumprijsbinding op dat moment geen prioriteit hadden. ${ }^{19}$

Dit beleid vertaalde zich ook in de handhavingspraktijk. In 2009 koos de NMa ervoor om niet te handhaven op basis van signalen die zij had ontvangen over RPM. Deze signalen ontving de NMa nadat zij een publieke oproep deed om problemen rondom internetverkoop te melden. Uit het onderzoek dat daarop volgde, bleek dat diverse webwinkels naar eigen zeggen werden gedwongen om de adviesverkoopprijzen van de leverancier te volgen. ${ }^{20}$ De NMa stelt daarop dat 'volgens recente economische literatuur [...] er ook situaties [zijn] waarin verticale prijsbinding positief uitwerkt' en dat 'verticale prijsbinding met name schadelijk is bij horizontale effecten'. ${ }^{21}$ Uit de ontvangen signalen bleken zulke horizontale effecten evenwel niet, aldus de NMa, en de NMa besloot dan ook niet tot nader onderzoek over te gaan.

Enkele jaren later, in 2014, leek het alsof de prioriteiten van de ACM langzaamaan aan het verschuiven waren. In een toespraak bij het Jaarcongres Ontwikkelingen Mededingingsrecht bevestigde de toenmalige bestuursvoorzitter Chris Fonteijn dat verticale overeenkomsten 'in het verleden weinig prioriteit' hadden bij de autoriteit. ${ }^{22}$ Fonteijn gaf aan dat economische ontwikkelingen aanleiding gaven tot een herziening van dit beleid, met meer nadruk op 'schadelijke verticale beperkingen'.

Het is echter maar de vraag of er vanaf dat moment een daadwerkelijke verschuiving van beleid plaatsvond. Dat bleek onder meer uit het Visiedocument van de ACM over verticale afspraken uit 2015 (hierna: het Visiedocument). ${ }^{23}$ Volgens het Visiedocument legt de ACM in haar prioritering de nadruk op het effect dat een verticale afspraak heeft op de consumentenwelvaart. Vervolgens geeft het Visiedocument aan dat verticale overeenkomsten normaliter vaker positieve effecten

Expedia Inc./Autorité de la concurrence e.a., ECLI:EU:C:2012:795, punt 35.

19. De toespraak van Kalbfleisch wordt besproken in: F. van Harinxma 'Verticale prijsbinding: geen prioriteit?', Actualiteiten Mededingingsrecht 2007, nr. 3, p. 47. Dit wil overigens niet zeggen dan de NMa RPM niet als overtreding ziet. In 2005 bracht de NMa een persbericht naar buiten waarin zij uitdrukkelijk zegt dat RPM niet is toegestaan: www.acm.nl/nl/publicaties/publicatie/5358/NMa-verticaleprijsbinding-niet-toegestaan.

20. NMa, 'Sectorscan - Signalen internetverkoop', juni 2009. Met de oproep leek NMa vooral te willen kijken naar duale prijsstelling online/ offline, wat nauw verbonden is met RPM.

21. NMa, 'Sectorscan - Signalen internetverkoop', juni 2009, p. 4.

22. Speech Chris Fonteijn op het congres 'Ontwikkelingen Mededingingsrecht 2014', 2 oktober 2014.

23. Of zoals Chris Fonteijn zegt in zijn toespraak op het Jaarcongres Ontwikkelingen Mededingingsrecht 2015 over het visiedocument (een jaar na zijn eerder besproken toespraak in 2014 op datzelfde congres): ‘[h]et resultaat is misschien geen enorme trendbreuk, het betekent wel dat we kritisch kijken naar overeenkomsten die mogelijk schade voor consumenten opleveren'. Voor een interessante bespreking van dit Visiedocument zie: M.K. Wijckmans, 'Toezicht ACM op verticale overeenkomsten', Mededingingsrecht in de Praktijk 2015, nr. 6, 2015/237. 
hebben dan negatieve effecten. ${ }^{24}$ Wat betreft RPM verwijst het Visiedocument naar economische literatuur die in twijfel trekt of dergelijke praktijken daadwerkelijk schadelijke effecten hebben (waarover hieronder meer). Het Visiedocument gaf al met al dus geen indicatie dat de ACM actiever zou gaan handhaven op verticale beperkingen, waaronder RPM.

$\mathrm{Na}$ het Visiedocument bleef het enige tijd stil, maar inmiddels lijkt de ACM een stevige stap te hebben gezet in de richting van meer handhaving. Begin 2019 heeft het Visiedocument plaatsgemaakt voor een nieuwe Leidraad over verticale afspraken. ${ }^{25}$ De Leidraad behandelt het algemene kader van de mededingingsrechtelijke beoordeling van afspraken tussen leveranciers en distributeurs. Uit de Leidraad blijkt niet duidelijk wat de precieze beweegredenen waren voor de herziening, maar het is duidelijk dat het voorgestelde beleid minder hands-off is dan voorheen. Anders dan in het Visiedocument volgt de nieuwe Leidraad de strakke lijn van de Europese Groepsvrijstelling en de Richtsnoeren. Dat betekent een formelere aanpak, met minder oog voor de concrete effecten op de consumentenwelvaart. Zo beschouwt de Leidraad RPM als een hardcore-beperking, zonder dat de ruimte wordt benoemd om een dergelijke beperking te rechtvaardigen aan de hand van het effect op de consumentenwelvaart. De eerder door de ACM uiteengezette focus op het effect op de consumentenwelvaart komt vrijwel niet terug in de Leidraad. ${ }^{26}$

De Leidraad lijkt dus te bevestigen dat de ACM actiever zal optreden tegen RPM. Dat blijkt ook uit de bedrijfsbezoeken die de ACM kort daarvoor heeft uitgevoerd in het kader van een onderzoek naar vermeende RPM. ${ }^{27}$

\section{Handhaving door andere mededingingsautoriteiten}

Het lijkt duidelijk dat de ACM meer prioriteit zal toebedelen aan RPM. Dat is zeker geen ontwikkeling die op zichzelf staat: de Commissie en enkele andere mededingingsautoriteiten in EU-landen gingen de ACM voor met een actievere handhaving van RPM.

In 2017 publiceerde de Commissie het rapport over haar sectoronderzoek naar e-commerce. ${ }^{28}$ Volgens het onder-

24. $A C M$, 'Het toezicht van ACM op verticale overeenkomsten - Inzicht in strategie \& prioritering', 20 april 2015, p. 15.

25. ACM, 'Leidraad. Afspraken tussen leveranciers en afnemers', 26 februari 2019.

26. Slechts eenmaal verwijst de Leidraad naar haar algemene prioriteringsbeleid, waarin het effect op de consumentenwelvaart een relevante factor is. Leidraad. Afspraken tussen leveranciers en afnemers, rnr. 27.

27. Nieuwsbericht $A C M$ : 'ACM onderzoekt prijsafspraken tussen fabrikanten en winkeliers consumentengoederen', 27 december 2018

28. Verslag van de Commissie aan de Raad van het Europees Parlement: 'Eindverslag over sectoronderzoek naar e-commerce', 10 mei 2017 ; Persbericht Europese Commissie: 'Antitrust: Commission publishes final report on e-commerce sector inquiry', 10 mei 2017. Zie ook: Y. de Vries, P.J.F. Huizing en W.E. Mink, 'Het sectoronderzoek e-commerce is afgerond: wat brengt het ons?', Mededingingsrecht in de Praktijk 2017, nr. 4, 2017/204. zoek maakt de opkomst van e-commerce prijsstelling transparanter, waardoor meer prijsconcurrentie ontstaat. In reactie hierop hebben fabrikanten onder meer getracht over te gaan tot mededingingsbeperkende maatregelen om de distributie te controleren. Verder stelt het onderzoek dat die mededingingsbeperkingen doeltreffender zijn doordat producten met digitale prijsmonitoringssystemen nagenoeg real time kunnen bijhouden welke distributeur welke prijs rekent. Prijsbeperkingen waren dan ook veruit de meest voorkomende beperking die uit het marktonderzoek naar voren kwamen. De Commissie concludeert dat zij haar handhaving zal concentreren op de meest voorkomende handelspraktijken die zijn ontstaan door de groei van e-commerce. Hierbij wordt RPM niet specifiek genoemd, maar met het oog op het voorgaande is duidelijk dat de Commissie dit onderwerp in de schijnwerpers zet. De Commissie geeft hierbij aan dat ze ook met nationale mededingingsautoriteiten de dialoog aan zal gaan, om zo te komen tot een consistente aanpak van de mededingingsregels. ${ }^{29}$

Met deze conclusies in het achterhoofd, is het geen verrassing dat recent verschillende nationale mededingingsautoriteiten handhavingsacties ondernamen. Zo legde de autoriteit in Denemarken begin 2019 een boete op aan een distributeur van haarproducten vanwege RPM, naar aanleiding van een klacht. ${ }^{30}$ Hetzelfde gebeurde begin 2019 in België met een importeur van infraroodcabines. ${ }^{31}$ Ook de autoriteiten in Duitsland (januari 2019), Frankrijk (december 2018) en Griekenland (september 2018) legden boetes op voor RPM. ${ }^{32}$ Zoals hierboven beschreven legde ook de Commissie medio 2018 haar eerste boetes in jaren op tegen RPM. De laatste keer was vijftien jaar geleden, toen de Commissie Yamaha beboette voor marktverdeling en RPM. ${ }^{33}$ Voor veel van deze jurisdicties geldt - in tegenstelling tot de ACM - dat de recente handhaving op RPM geen nieuwe ontwikkeling is. ${ }^{34} \mathrm{Zo}$ werden in Duitsland al in 2009 boetes opgelegd voor RPM aan een producent van

29. Verslag van de Commissie aan de Raad van het Europees Parlement: 'Eindverslag over sectoronderzoek naar e-commerce', 10 mei 2017, p. 18-19.

30. Persbericht Deense Mededinging en Consumenten Autoriteit: 'Denmark: Distributor of hair products sentenced to pay a fine of DKK 1,000,000 for resale price maintenance', 15 februari 2019.

31. Persbericht Belgische Mededingingsautoriteit Nr. 3/2019: 'Het Auditoraat van de BMA neemt een transactiebeslissing wegens het opleggen van maximale kortingsniveaus aan een netwerk van distributeurs en legt een boete op ten bedrage van EUR 98.000', 29 januari 2019.

32. Persbericht Franse Mededingingsautoriteit: 'The Autorité hands down fines for anticompetitive practices to several producers and wholesale distributors of liquid fertilisers', 20 december 2018, te raadplegen via: www.autoritedelaconcurrence.fr/user/standard.php?lang=fr\&id_rub= 684\&id_article=3311; Persbericht Bundeskartellamt: 'Fine imposed on bicycle wholesaler ZEG for vertical price-fixing', 29 januari 2019, te raadplegen via: www.bundeskartellamt.de/SharedDocs/Meldung/EN/ Pressemitteilungen/2019/29_01_2019_Fahrrad.html;jsessionid=09C91 672391A80DCF9F568595CD732A6.1_cid362?nn=3591568; Griekenland, persbericht van 9 september 2018, www.epant.gr/en.

33. Persbericht Europese Commissie: 'Commission fines Yamaha for restrictions of trade and resale price maintenance in Europe', 16 juli 2003, te raadplegen via: http://europa.eu/rapid/press-release_IP-03-1028_ en.htm?locale=en.

34. Zie voor een nuttig overzicht van eerdere handhaving op gebied van RPM: De Vries, Rutges en Vollering 2014; R. Elkerbout, 'Verticale prijs- 
contactlenzen ${ }^{35}$ en een producent van gehoorapparaten. ${ }^{36}$ In 2009 verklaarde de BKA dat de Europese benadering om RPM te zien als een hardcore-beperking juist is, en dat het een stap in de verkeerde richting zou zijn om RPM niet in beginsel te beschouwen als een mededingingsbeperking. ${ }^{37}$ In de jaren daarna legde het BKA verschillende boetes op. ${ }^{38}$ Onder meer deed de BKA in 2015 en 2016 een grootschalig onderzoek naar RPM in de supermarktsector, met meerdere boetes tot gevolg. ${ }^{39}$ Ook het Verenigd Koninkrijk heeft in het verleden meerdere boetes opgelegd, zoals in 2016 (koelkasten ${ }^{40}$ en sanitair ${ }^{41}$ ) en in 2017 (lampen $^{42}$ ). Eerder al, in 2014, komt de Britse autoriteit in actie tegen adviesprijzen voor scootmobiels. ${ }^{43}$ In 2017 publiceerde de CMA op haar website een stevige open brief aan leveranciers en retailers over de ernst van RPM, in navolging op een eerder advies uit $2016 .{ }^{44}$ In april dit jaar bracht de CMA een statement of objections uit aan pianoverkoper Casio voor RPM. ${ }^{45}$

Ook in andere jurisdicties is handhaving op RPM niet nieuw. De Franse autoriteit besloot onder meer in 2006 (luxe parfums) en 2007 (speelgoed) tot het opleggen van boetes voor RPM. ${ }^{46}$ Ook interessant: in 2017 legt de Franse autoriteit een boete op voor misbruik van machtspositie, waarbij het misbruik bestond uit RPM. ${ }^{47}$ In Oostenrijk staat RPM ook al lang op de agenda. In 2014 publiceerde de Bundeswettbemerbsbehörde richtsnoeren over RPM, met daarin een strakke lijn ten

binding: the bad, the ugly and... the good?', Mededingingsrecht in de Praktijk 2018, nr. 1, 2018/46.

35. Persbericht Bundeskartellamt, 'Bundeskartellamt imposes fine on CIBA Vision', 25 september 2009.

36. Persbericht Bundeskartellamt, 'Bundeskartellamt imposes fine on hearing aid manufacturer Phonak GmbH', 15 oktober 2009.

37. Zie: OECD, 'Roundtable on Resale Price Maintanence', DAF/ $\operatorname{COMP}(2008) / 37,10$ september 2009.

38. Bijvoorbeeld in 2012 voor RPM bij gereedschap (Tooltechnic); in 2015 bij matrassen (Tempur) en draagbare navigatiesystemen (United Navigation); in 2016 voor Lego (LEGO); in 2017 voor meubels (verschillende ondernemingen) en in 2018 voor kleding (Wellensteyn).

39. Persbericht Bundeskartellamt: 'Fine proceedings for vertical price fixing in the German food retail sector concluded', 15 december 2016. In juli 2017 publiceerde de BKA vervolgens een guidance note over het verbod op 'vertical price fixing' specifiek in de fysieke retailsector voor voedingswaren. BKA, 'Guidance note on the prohibition of vertical price fixing in the brick-an-mortar food retail sector', juli 2017.

40. Persbericht CMA, 'Fridge supplier fined $£ 2.2$ million for restricting online discounts', 24 mei 2016.

41. Persbericht $C M A$, 'CMA issues bathroom fittings infringement decision and fine', 10 mei 2016.

42. Persbericht $C M A$, 'Lighting company fined $£ 2.7$ million for restricting online prices', 20 juni 2017; Case study CMA: 'Resale price maintenance case studies', 21 juni 2016

43. Nieuwsbericht CMA, 'CMA publishes decision on mobility scooters', 30 oktober 2014.

44. CMA, 'Collection - Information for businesses: resale price maintenance (RPM)', op: www.gov.uk/government/publications/resale-pricemaintenance-advice-for-retailers/resale-price-maintenance-advice-forretailers.

45. Persbericht $C M A,{ }^{\prime} C M A$ alleges piano supplier illegally prevented price discounts', 11 april 2019.

46. Respectievelijk Décision $n^{\circ}$ 06-D-04 en 07-D-50 van de Conseil de la Concurrence.

47. Persbericht Autorité de la Concurrence, 'The Autorité de la concurrence fines Obut for having obliged its dealers to charge suggested retail prices', 10 februari 2017 opzichte van RPM. ${ }^{48}$ Zowel daarvoor als daarna stelde de Oostenrijkse kartelrechtbank boetes vast voor RPM. $^{49}$

Hoewel de vorige paragrafen geen uitputtend beeld geven van handhaving op het gebied van RPM in Europa, blijkt hier wel uit dat het onderwerp in veel landen al geruime tijd op de agenda staat.

Deze ontwikkelingen op Europees niveau en op nationaal niveau laten ook hun sporen na in het Nederlandse mededingingsrecht. Immers, het Nederlandse mededingingsrecht is niet strenger, maar ook niet minder streng dan het Europese mededingingsrecht. Het klopt dat nationale mededingingsautoriteiten de ruimte hebben om hun eigen accenten te leggen, bijvoorbeeld aan de hand van specifieke nationale marktomstandigheden. In het geval van $e$-commerce is het echt niet goed uitlegbaar waarom RPM in België, Duitsland en Frankrijk wél problematisch zou zijn, en in Nederland niet. Aangezien de marktomstandigheden dichter naar elkaar gegroeid zijn, is het niet vreemd dat er een wens leeft bij de autoriteiten om het beleid nader op elkaar af te stemmen. De volgende paragraaf gaat nader in op de verandering in de aanpak van de ACM en hoe zich die verhoudt tot het beleid van de Commissie.

\section{De nieuwe koers van de ACM}

\section{Strenger beleid}

Zoals hiervoor besproken was RPM tot voor kort geen prioriteit van de ACM. Met de recente invallen en de nieuwe Leidraad is daarin verandering gekomen. Aangezien de invallen nog niet hebben geleid tot besluiten, zal de analyse hieronder voornamelijk ingaan op het beleid zoals de Leidraad die uiteenzet. De volgende paragraaf gaat nader in op de recente settlement decisions van de Commissie, en de vraag of de ACM een vergelijkbare koers zou moeten varen. Maar eerst het beleid.

Bij het lezen van de nieuwe Leidraad valt één ding direct op: de tekst volgt strak de systematiek van de Groepsvrijstelling en de bijbehorende Richtsnoeren. In die zin brengt de Leidraad juridisch niets nieuws. Toch staat dit in duidelijk contrast met het eerdere Visiedocument uit 2015. Daarin legt de ACM de nadruk voornamelijk op haar eigen prioriteringsbeleid, met het economische effect op de consumentenwelvaart als centrale focus. In het Visiedocument benadrukte de ACM nog dat de economische literatuur helemaal niet negatief staat tegenover verticale beperkingen. Van een strakke lijn ten opzichte van RPM was dan ook geen sprake. De Leidraad heeft daarmee een duidelijk andere insteek dan het Visiedocument. Waar het voormalige Visiedocument vooral de nadruk legde op het verdedigen van het laissez faire-beleid dat de ACM indertijd volgde, kent de

48. Bundeswettbewerbsbehörde, 'Standpoint on Resale Price Maintenance', juli 2014.

49. Bijvoorbeeld in 2013 aan Philips voor RPM bij consumentenelektronica, en een viertal boetes in 2016 en 2017 voor De'Longhi-Kenwood, Makita, Robopolis and Pioneer \& Onkyo. 
Leidraad vooral een (droge) uiteenzetting van het Europees juridisch kader dat veel sceptischer is richting RPM. Met deze strengere benadering richting RPM gaat de ACM meer in de 'Europese pas' lopen, in de woorden van ACM-bestuursvoorzitter Snoep. ${ }^{50}$

Meer specifiek zijn er ten aanzien van RPM duidelijke verschillen te constateren tussen de Leidraad en het Visiedocument. Met name op het punt van mogelijke efficiencies is de ACM van standpunt gewijzigd. De ACM schrijft in de Leidraad dat 'hardcore beperkingen zoals verticale prijsbinding $[\ldots]$ de mededinging [beperken] en [zelden] [voldoen] aan de voorwaarden van de uitzondering voor efficiëntieverbeteringen'. ${ }^{51} \mathrm{De}$ ACM sluit dus nauwer aan bij de systematiek die geldt volgens de Groepsvrijstelling en de Richtsnoeren. Hiermee neemt zij impliciet afstand van de - veel soepelere positie die zij eerder innam. ${ }^{52}$

Zoals hierboven aangegeven stelde de ACM in haar Visiedocument nog dat verticale afspraken 'vaker wel dan niet ten goede komen aan de consumentenwelvaart'. ${ }^{53}$ Zelfs ten aanzien van RPM is de ACM niet zonder meer kritisch. De ACM verwijst niet alleen naar economisch onderzoek waaruit de negatieve welvaartseffecten van RPM zouden blijken, maar juist ook op onderzoek waarin die negatieve effecten worden genuanceerd. ${ }^{54}$ Het Visiedocument leek daarmee een case-by-case analyse voor te staan, met daarbij de expliciete mogelijkheid dat 'zelfs' RPM gerechtvaardigd kan zijn. Ook in de eerdere sectorscan internetverkoop stond de ACM duidelijk meer open voor mogelijke positieve effecten door efficiënte verbeteringen. De ACM wijst onder meer op literatuur die de positieve effecten van RPM onderschrijft. ${ }^{55}$ Dit alles onderstreept de eerdere woorden van Kalbfleisch dat RPM op dat moment geen prioriteit was voor de ACM. ${ }^{56}$

50. Zie de opmerkingen van Martijn Snoep, de huidige bestuursvoorzitter van de ACM. Over de nieuwe Leidraad licht Snoep toe: 'We hebben in februari jl. een nieuwe leidraad verticale overeenkomsten uitgebracht. Daarin hebben we duidelijk gezegd: we volgen de lijn van de Europese Commissie en de jurisprudentie van het Hof van Justitie, waarin we een verticale prijsbinding als een strekkingsbeding beschouwen en als zodanig zullen behandelen. Het is een bewuste keuze geweest van de ACM om geen uitzonderingspositie in de $\mathrm{EU}$ in te nemen. Los van de vraag of we dat in het verleden wel deden, willen we nu gewoon in de Europese pas lopen.', zie C.T. Dekker, A. Gerbrandy en G. Niels, “'Wij staan op het punt om uit het peloton te demarreren naar de koplopers" - Interview met Martijn Snoep door redactie Markt \& Mededinging', M\&M 2019/3, p. 87.

51. Leidraad. Afspraken tussen leveranciers en afnemers, rnr. 26.

52. Zie voor een overzicht van de eerdere - uitblijvende - handhaving van de ACM op het gebied van RPM: De Vries, Rutges en Vollering 2014 en Elkerbout 2018.

53. ACM, 'Het toezicht van ACM op verticale overeenkomsten - Inzicht in strategie \& prioritering', 20 april 2015, p. 15.

54. $\mathrm{ACM}$, 'Het toezicht van ACM op verticale overeenkomsten - Inzicht in strategie \& prioritering', 20 april 2015, p. 15.

55. Zie: NMa, 'Sectorscan - Signalen internetverkoop', juni 2009, p. 4: 'volgens recente economische literatuur [zijn] er ook situaties waarin verticale prijsbinding positief uitwerkt'. Ook staat er dat 'verticale prijsbinding met name schadelijk is bij horizontale effecten'.

56. De toespraak van Kalbfleisch wordt besproken in: F. van Harinxma 'Verticale prijsbinding: geen prioriteit?', Actualiteiten Mededingingsrecht 2007, nr. 3, p. 47.
Interessant is dat het sectoronderzoek van de Commissie naar e-commerce wel tot een strenger standpunt over RPM heeft geleid, terwijl een eerdere scan van de Nederlandse autoriteit in dezelfde sector - ondanks signalen - geen reden gaf tot ingrijpen. Het is onduidelijk wat precies de reden is voor dit verschil in uitkomst. In de sectorscan e-commerce concludeert de Commissie dat ingezet moet worden op een consistent Europees beleid op verticale afspraken. De ACM lijkt zich hierbij met de nieuwe Leidraad en de recente invallen te hebben aangesloten. Die duiden op een zichtbaar strengere houding van ACM met betrekking tot RPM.

De rol van efficiencies

Hoewel de Commissie de wens heeft uitgesproken voor consistent beleid door heel Europa, blijven cruciale vragen onbeantwoord. Zo is het afwachten welke rol efficiëntieverbeteringen zullen gaan spelen bij de rechtvaardiging van RPM. Hoewel de Richtsnoeren enig inzicht geven in de verweren die kunnen worden gevoerd, blijft grotendeels onduidelijk hoe de autoriteiten hiermee om zullen gaan. Dat vraagt om meer informele guidance, zoals ook bij veel andere categorieën van verticale overeenkomsten het geval is. ${ }^{57}$

De Leidraad geeft alvast enkele handvatten over de wijze waarop de ACM het verbod op RPM ziet. De ACM legt daarin de nadruk op het criterium van onmisbaarheid, en illustreert dat aan de hand van een voorbeeld. Interessant detail daarbij is dat de ACM in een nagenoeg identieke casus in het eerdere Visiedocument nog tot de conclusie kwam dat een dergelijke zaak geen prioriteit zou hebben voor de ACM. ${ }^{58}$

Die casuspositie gaat in essentie om de situatie waarin een leverancier sancties oplegt aan distributeurs die zich niet aan een prijsadvies houden. De leverancier heeft een gering marktaandeel en ondervindt stevige concurrentie. Omdat het hier gaat om een complex product, kan mogelijk een beroep worden gedaan op efficiëntieverbeteringen omdat meeliftproblemen voorkomen worden. RPM zou dan nodig zijn om te garanderen dat een bepaalde service wordt verleend bij het kopen van een product, waardoor wordt voorkomen dat goedkopere aanbieders kunnen meeliften op de service van anderen. Zoals gezegd gaat de ACM primair in op het criterium van onmisbaarheid. De leverancier moet volgens de ACM aannemelijk maken dat er geen andere reële alternatieven zijn om te garanderen dat de nodige service wordt verleend. Als mogelijk alternatief noemt de ACM een selectief distributiestelsel, waarbij de leverancier kan verplichten dat distributeurs service verlenen. Als een selectief distributiesysteem in de specifieke omstandigheden van het geval inderdaad wordt gezien als een reëel alternatief, zal RPM niet snel gerechtvaardigd zijn. De vraag is wat dat betekent. Stel dat de ACM er aldus van uitgaat dat RPM in beginsel de concurrentie beperkt.

57. Zie bijvoorbeeld Richtsnoeren, par. 149-150, 165-167, 173, 187-188, 191, 202.

58. Vergelijk Scenario 2 uit het Visiedocument en Voorbeeld 8 uit de Leidraad, beide met titel 'het stimuleren van service bij sterke interbrand concurrentie'. Beide casussen gaan over de verkoop van gereedschap. 
En stel ook dat de ACM - in lijn met de voorgaande casuspositie - een strenge interpretatie hanteert van het onmisbaarheidscriterium. In dat geval zou de handhaving van RPM opeens uitermate (en: veel te) ruim kunnen zijn - een switch van het eerdere laissez faire naar het andere uiterste, namelijk een bijzonder streng verbod. Uiteraard is het moeilijk om dergelijke conclusies te trekken aan de hand van één casuspositie die de ACM beschrijft. Mogelijk wordt de soep uiteindelijk niet zo heet gegeten, en bedoelt de ACM vooral te signaleren dat ze streng zal toezien op de onmisbaarheid, zonder dat zij zegt dat het in de praktijk vrijwel onmogelijk zal zijn om daaraan te voldoen. Niettemin is het opmerkelijk dat er een aanzienlijke shift heeft plaatsgevonden, en dat zonder een duidelijke uitleg van het economische denkkader, terwijl de ACM juist jarenlang het belang heeft benadrukt van een economische analyse om te bepalen of RPM nu juist wel of niet door de beugel kan.

\section{Medewerking en boetekorting}

De hernieuwde focus op RPM heeft niet enkel implicaties voor (de toepassing van) het materiële recht, maar ook voor de procedures die worden gevolgd. Opvallend aan de vier recente Commissiebeschikkingen is dat zij alle het resultaat zijn van een schikkingsprocedure (althans een variant daarvan), waarbij de Commissie 40 tot 50 procent korting geeft op de boetes. Hiermee lijkt de Commissie een nieuwe procedure in het leven te roepen. Voorheen paste de Commissie een zogenoemde settlement decision enkel toe in kartelzaken, met bovendien een boetekorting van slechts 10 procent. ${ }^{59}$ Hogere kortingen in kartelzaken komen voor bij clementieaanvragen.

Ook in de Guess-beschikking (december 2018) en de recente Hello Kitty-zaak (juli 2019), beide over het beperken van grensoverschrijdende verkoop, geeft de Commissie hoge kortingen voor samenwerking. Hetzelfde geldt voor de eerdere $A R A$-beschikking, met een korting van 30 procent. ${ }^{60}$ In de persberichten van de Guessen Hello Kitty-zaken verwijst de Commissie naar een Fact Sheet getiteld 'Cooperation - FAQ' ${ }^{61}$

In de Fact Sheet geeft de Commissie aan dat samenwerkingsprocedures ook kunnen gelden buiten kartelzaken en geeft zij vervolgens een raamwerk voor dergelijke procedure. De Commissie bekijkt zaak voor zaak of deze zich leent voor een schikking. Hoewel de Commissie de procedure niet als een clementieaanvraag classificeert, hanteert zij wel als voorwaarde dat de onderzochte

59. Zie voor het beleid van de Commissie hieromtrent: http://ec.europa.eu/ competition/cartels/legislation/cartels_settlements/settlements_en.html. Hier staat expliciet dat schikken alleen kan in kartelzaken: 'Does the settlement procedure apply to other antitrust cases? No, cartels only.'

60. Persbericht Commissie, 'Antitrust: Commission fines ARA $€ 6$ million for hindering competition on Austrian waste management market', 20 september 2016.

61. Zie http://ec.europa.eu/competition/publications/data/factsheet guess.pdf. onderneming de inbreuk erkent. De hoogte van de boetekorting hangt af van de mate van samenwerking en de timing daarvan. Zo zal erkenning van de inbreuk voordat de punten van overweging zijn uitgebracht, meer korting opleveren dan een erkenning naderhand. Een en ander hangt samen met de mate waarin de samenwerking een efficiëntere procedure tot gevolg heeft. Hoe meer efficiëntie, hoe hoger de korting, zo lijkt de insteek.

De ACM biedt een dergelijke procedure (nog) niet aan. Wel heeft de ACM in de afgelopen jaren diverse boetezaken vereenvoudigd afgedaan mede met het oog op een efficiënte afdoening. ${ }^{62}$ Dit is echter iets anders dan de Commissie doet; de boetekorting is namelijk niet hoger dan 10 procent en de ACM benadrukt dat het geen schikking is. ${ }^{63}$ De ACM lijkt voorlopig niet van plan om een schikkings- of clementieregeling in het leven te roepen voor RPM. ${ }^{64}$ In april van dit jaar zei Martijn Snoep hierover dat de ACM eerst het beleid helder wil neerzetten. Als blijkt dat er dan voldoende klachten binnenkomen, is het openzetten van een clementieregeling niet nodig, aldus Snoep. ${ }^{65}$

Vanuit een opsporingsoogpunt is een clementieregeling voor RPM inderdaad minder van belang dan bij kartels. RPM kan immers aan het licht komen door klachten van onvrijwillig verbonden derden en is mogelijk (zelfs) vastgelegd in contracten. Toch geldt voor zowel kartels als voor RPM dat de ACM voordeel kan doen met een efficiëntere procedure als gevolg van medewerking. Ook loopt de ACM dan geen risico op een rechterlijke vernietiging van haar besluit. Een dergelijke procedure zou dan - net als bij de Commissie - niet zozeer ingestoken hoeven te worden als een clementieregeling, maar eerder als een schikkingsregeling. In andere landen, zoals het Verenigd Koninkrijk en Luxemburg, staat de clementieprocedure wel open voor RPM. ${ }^{66}$ Voor zover de ACM

62. Zie onder meer: Besluit ACM 25 juni 2015, zaak 14.0705.27 met kenmerk ACM/DJZ/2015/203320_OV - (Natuurazijn); Besluiten ACM 22 december 2015, zaken 13.0698.31 en 15.0327.31 met kenmerken ACM/DJZ/2015/207566_OV en ACM/DJZ/2015/207552_OV - (Koelen vrieshuizen); en Besluit ACM 30 juni 2017, zaak 7615 met kenmerk 7615_11/84 - (Tractiebatterijen). Ook in andere zaken dan kartelzaken is gebruikgemaakt van vereenvoudigde afdoening: Besluit ACM 26 mei 2016, zaak 15.1118.52 met kenmerk ACM/DJZ/2016/202396_OV (Te hoge roamingtarieven). Eind vorig jaar kwam de ACM met richtsnoeren over vereenvoudigde afdoening, waaruit blijkt dat een dergelijke procedure kan worden toegepast voor elk soort overtreding. De boetekorting is gelimiteerd tot 10 procent. De ACM benadrukt daarbij dat de vereenvoudigde afdoening geen schikkingsprocedure is.

63. $A C M$, 'Richtsnoeren vereenvoudigde afdoening boetezaken ACM Vragen en antwoorden', 21 december 2018.

64. Martijn Snoep zegt daarover: 'vooralsnog is het niet nodig om het clementieprogramma open te stellen voor verticale prijsafspraken, maar dat kan veranderen', zie Dekker, Gerbrandy en Niels 2019, p. 87.

65. Dekker, Gerbrandy en Niels 2019, p. 87. In een column uit 2016 pleit Martijn Snoep nog voor een clementieregeling voor RPM: T.M. Snoep, 'In de kartelhel is nog plaats', M\&M 2016/3.

66. Op de website van de CMA wordt op de pagina over RPM verwezen naar het clementieprogramma, zie: www.gov.uk/government/ publications/resale-price-maintenance-advice-for-retailers/resale-pricemaintenance-advice-for-retailers. De autoriteit in Luxemburg geeft aan dat clementie openstaat voor verticale afspraken (zonder dit te limiteren tot RPM), zie: https://concurrence.public.lu/fr/decisions/ententes/ 2016/decision-2016-as-05.html. 
RPM steeds meer zou gaan beschouwen als een hardcore-overtreding, ligt het in de rede na te gaan of ook het procedurele raamwerk nader kan worden aangesloten met de horizontale hardcore-overtredingen - of dat nu in de vorm is van een schikkingsregeling of een clementieregeling.

\section{Conclusie}

Jarenlang gaf de ACM, in tegenstelling tot andere nationale mededingingsautoriteiten, weinig prioriteit aan verticale beperkingen waaronder RPM. Vooral door de opkomst van e-commerce staat RPM tegenwoordig extra in de schijnwerpers: RPM is doorgaans makkelijker te verwezenlijken in de digitale wereld dan in de traditionele retail, en tegelijk is RPM ook makkelijker om te constateren door kopers - en dus klachtgevoeliger.

De recente Leidraad van de ACM geeft een veel strengere positie weer ten opzichte van verticale overeenkomsten dan ACM's eerdere beleidsdocumenten. De vraag is op welke manier haar gewijzigde beleidsvisie zich zal vertalen naar de beschikkingspraktijk. De recente invallen gericht op vermeende RPM lijken alvast een schot voor de boeg. Een kernvraag is hoe de ACM om zal gaan met het te onderzoeken effect van RPM: gaat zij in beginsel uit van het schadelijke welvaartseffect daarvan (zoals het Europese raamwerk doet) of juist niet (waar ACM's beleid jarenlang van uit is gegaan)? Dat is tevens relevant voor hoe moeilijk of gemakkelijk het in de praktijk is om efficiencies aan te tonen.

Hoe dan ook: met dit strengere beleid loopt de ACM weer steviger in de 'Europese pas'. Het is afwachten in hoeverre de handhaving in de verschillende jurisdicties een consistent beeld zal laten zien, conform de wens die de Commissie in het sectoronderzoek e-commerce heeft uitgesproken. Wellicht dat de Commissie de herziening van de Groepsvrijstelling en Richtlijnen kan aangrijpen om een duidelijke Europese lijn uit te zetten. De vraag is of dat op tijd is, gezien de (steeds) actieve(re) handhaving van vele nationale mededingingsautoriteiten. 